\title{
Acute HIV infection presenting as hemophagocytic lymphohistiocytosis: case report and review of the literature
}

\author{
Farheen Manji ${ }^{1 *} \mathbb{D}$, Evan Wilson ${ }^{1}$, Etienne Mahe ${ }^{1}$, John Gill ${ }^{1}$ and John Conly ${ }^{1,2^{*}}$
}

\begin{abstract}
Background: Hemophagocytic lymphohistiocytosis $(H L H)$ is an uncommon systemic inflammatory condition that can result from infections, autoimmune diseases and malignancies. It is a rarely reported life threatening complication of an acute HIV infection, with only ten documented case reports per our literature search. We present a case of HLH secondary to acute HIV infection with a negative HIV antibody-based assay and high plasma viral load.

Case presentation: A 45 year old male with a past medical history of well controlled hypertension presented with fever, dizziness and non-bloody diarrhea. Initial lab work revealed a new thrombocytopenia, marked renal failure and an elevated creatine kinase, ferritin, lactate dehydrogenase and D-dimer. A bone marrow biopsy revealed $\mathrm{HLH}$. As part of the work up for thrombocytopenia, a rapid HIV antibody based assay was done and was negative. The sample was later routinely tested with a fourth generation antigen/antibody assay as per local protocol and was strongly positive. The plasma RNA viral load was $>10,000,000$ copies $/ \mathrm{mL}$ confirming the diagnosis of an acute HIV infection. The patient was urgently started on antiretroviral therapy and recovered.

Conclusion: This case illustrates a diagnostic approach to HLH which is an uncommon but life threatening multisystem disease, requiring the involvement of a multidisciplinary team of experts. Following any diagnosis of $H L H$, rapid identification and treatment of the underlying condition is critical. A negative rapid HIV antibody test can be misleading in the context of early HIV infection and the additional use of fourth generation antigen/antibody test or plasma RNA viral load may be required within the right clinical context for diagnosis.
\end{abstract}

Keywords: Hemophagocytic syndrome, HIV, Human immunodeficiency virus, Acute retroviral syndrome, Hemophagocytic lymphohistiocytosis

\section{Background}

Hemophagocytic lymphohistiocytosis (HLH) is rare and life-threatening immune activation syndrome that can be idiopathic or secondary to various infectious, inflammatory or neoplastic conditions (Table 1) [1-3]. HLH associated with HIV is rare, most often being described in those with chronic HIV infection or with the presence of concomitant opportunistic infections [4]. HLH associated with an acute HIV infection is even rarer, having been described in only a few case reports [5-12]. We report the case of a 45 year old male with life-threatening

*Correspondence: Farheen.manji@ahs.ca; john.conly@albertahealthservices.ca ${ }^{1}$ University of Calgary and Alberta Health Services, 1403-29th Street NW, Calgary, AB T2N 2T9, Canada

Full list of author information is available at the end of the article
HLH secondary to an acute HIV infection and a negative rapid antibody-based HIV test. HIV was diagnosed based on a fourth generation antigen/antibody based Enzyme Linked Immunoassay and plasma RNA viral load. The patient recovered with antiretroviral therapy (ART). In addition, we review the available literature on this topic.

\section{Case presentation}

A middle aged man with a history of controlled hypertension presented with a one week history of non-bloody diarrhea with fever and dizziness. He reported four to six non-bloody bowel movements a day for the one week prior to admission with subjective fevers and a sore throat. He reported being in a monogamous relationship with his wife and denied use of any illicit intravenous or oral drugs, alcohol or recent travel outside Canada. 
Table 1 Differential diagnosis of secondary hemophagocytic lymphohistiocytosis [1]

\begin{tabular}{cl}
\hline Infectious & \\
\hline Viral & Epstein-Barr Virus, Cytomegalovirus, \\
& Parvovirus, Herpes Simplex Virus, \\
& Varicella-Zoster Virus, Measles, \\
& Human Herpes Virus-8, H1N1 \\
Influenza Virus, Parechovirus, & HIV \\
& Brucella spp., Gram negative bacteria, \\
& Mycobacterium tuberculosis, \\
Bacterial & Staphylococcus aureus, \\
& Candida, Cryptococcus, Pneumocystis, \\
& Histoplasma, Aspergillus \\
Fungal & Plasmodium falciparum, Plasmodium \\
& vivax, Toxoplasma, Leishmania, Strongyloides \\
Parasitic & Systemic juvenile idiopathic arthritis, \\
Inflammatory & Kawasaki's disease systemic lupus \\
& erythematosus and other \\
& rheumatologic diseases \\
& T-cell/NK-cell lymphomas, anaplastic \\
large cell lymphomas, acute \\
lymphoblastic leukemia, Hodgkin's \\
lymphoma, various solid tumours \\
(prostate, lung, hepatocellular carcinoma) \\
Inherited or acquired immunodeficiency
\end{tabular}

Examination revealed a fever of $38.0^{\circ} \mathrm{C}$, heart rate of 76 , blood pressure of $163 / 100$ and a respiratory rate of 16 with saturations of $93 \%$ on room air. He had erythematous tonsils with no exudate and a clinical diagnosis of oral candidiasis. There was no rash, palpable lymphadenopathy or oral ulcers but he had mild bleeding of his gums. He had a fluctuant mass on his left upper thigh with purulent drainage. The rest of his exam was unremarkable.

The laboratory results are shown in Table 2 . He was found to have a marked thrombocytopenia and lymphopenia and an elevated creatinine with granular casts in his urine and a markedly elevated creatine kinase (CK). There was no evidence of hemolysis but he did have a high lactate dehydrogenase, ferritin and D-Dimer. The peripheral blood smear showed thrombocytopenia with no evidence of schistocytes. He had mild splenomegaly $(13.3 \mathrm{~cm}$, normal $<12 \mathrm{~cm})$ on ultrasound. On his third day of admission, one out of two sets of blood cultures was positive for methicillin-resistant Staphylococcus aureus (MRSA) at $22 \mathrm{~h}$ and two out of two blood cultures were positive for Streptococcus mitis (S.mitis) at $14 \mathrm{~h}$. The MRSA strain had a susceptibility profile typical for a community associated MRSA. Syphilis EIA testing and urine gonorrhea and chlamydia assays were negative. Anti-nuclear antibodies and $\mathrm{C} 3$ and $\mathrm{C} 4$ were negative. Hepatitis A IgG, was reactive, hepatitis B core antibody/antigen, and hepatitis B surface antigen were negative while the surface antibody was positive at $1.2 \mathrm{IU} / \mathrm{L}$. Hepatitis C core antibody was non-reactive.
Table $\mathbf{2}$ Laboratory values at presentation and after treatment

\begin{tabular}{|c|c|c|c|}
\hline & \multicolumn{2}{|c|}{ Patient lab values } & \multirow{2}{*}{$\begin{array}{l}\text { Normal } \\
\text { range }\end{array}$} \\
\hline & $\begin{array}{l}\text { At } \\
\text { admission }\end{array}$ & $\begin{array}{l}\text { After } 5 \text { weeks of } \\
\text { antiretroviral therapy }\end{array}$ & \\
\hline Hemoglobin, g/L & 159 & 117 & $137-180$ \\
\hline $\begin{array}{l}\text { White blood cell, } \\
\times 10^{9} / \mathrm{L}\end{array}$ & 3.0 & 3.2 & $4.0-11.0$ \\
\hline Platelets, $\times 10^{9} / \mathrm{L}$ & 50 & 207 & $150-400$ \\
\hline Sodium, mmol/L & 139 & 139 & $133-145$ \\
\hline Potassium, mmol/L & 3.4 & 4.0 & $3.3-5.1$ \\
\hline Chloride, $\mathrm{mmol} / \mathrm{L}$ & 107 & 108 & $98-111$ \\
\hline Bicarbonate, mmol/L & 16 & 24 & $21-31$ \\
\hline Creatinine, $\mu \mathrm{mol} / \mathrm{L}$ & 160 & 97 & $50-120$ \\
\hline $\begin{array}{l}\text { Total bilirubin, } \\
\mu \mathrm{mol} / \mathrm{L}\end{array}$ & 20 & 11 & $0-24$ \\
\hline Haptoglobin, g/L & 1.24 & & $0.30-2.00$ \\
\hline $\begin{array}{l}\text { Lactate } \\
\text { Dehydrogenase } \\
(\mathrm{LDH}), \mathrm{U} / \mathrm{L}\end{array}$ & 1739 & 242 & $100-235$ \\
\hline Ferritin, $\mu g / L$ & 69,717 & & $30-400$ \\
\hline D-dimer, mg/L & $>10$ & & $<0.46$ \\
\hline Fibrinogen, g/L & 2.0 & & $1.6-4.1$ \\
\hline $\begin{array}{l}\text { Creatine kinase, } \\
\text { U/L }\end{array}$ & 25,000 & 232 & 0-195 \\
\hline $\begin{array}{l}\text { Triglycerides, } \\
\mathrm{mmol} / \mathrm{L}\end{array}$ & 4.36 & & $0.60-2.30$ \\
\hline CD4 Count, $\times 10^{9} / \mathrm{L}$ & 0.137 & 0.275 & $0.499-1.651$ \\
\hline Viral load, copies/mL & $\begin{array}{l}>7.24 \log \\
\text { base } 10\end{array}$ & $1.96 \log$ base 10 & \\
\hline $\begin{array}{l}\text { HIV Architect 4th } \\
\text { generation assay }\end{array}$ & 615.18 & 27.3 & $<1$ \\
\hline Western blot & Negative & & Negative \\
\hline
\end{tabular}

Epstein-Barr Virus (EBV) IgM antibodies were negative and IgG antibodies were positive, consistent with a remote infection. Parvovirus B19 IgM and CMV IgM were negative. A rapid HIV antibody based assay (INSTITM HIV-1/HIV-2 Antibody Test Kit, bioLytical Laboratories Inc.) was negative.

Bone marrow biopsy revealed a hypocellular marrow with multifocal hemophagocytosis with no evidence of a neoplastic, parasitic or fungal process (Figs. 1 and 2).

The sample submitted for rapid HIV testing was later routinely tested with a fourth generation antigen/antibody assay (Abbott Architect, Abbott Illinois USA) as per local protocol. The test was strongly positive with a signal to cut off ratio of 615.18 (Normal $<1$ ) and the Western blot showed no antibody bands. The plasma RNA viral load was $>10,000,000$ copies/mL (Abbott Realtime Illinois USA), confirming the diagnosis of acute HIV infection. His CD4 count was low at $0.137 \times 10^{9} / \mathrm{L}$ (normal $0.499-1.651 \times 10^{9} / \mathrm{L}$ ). 


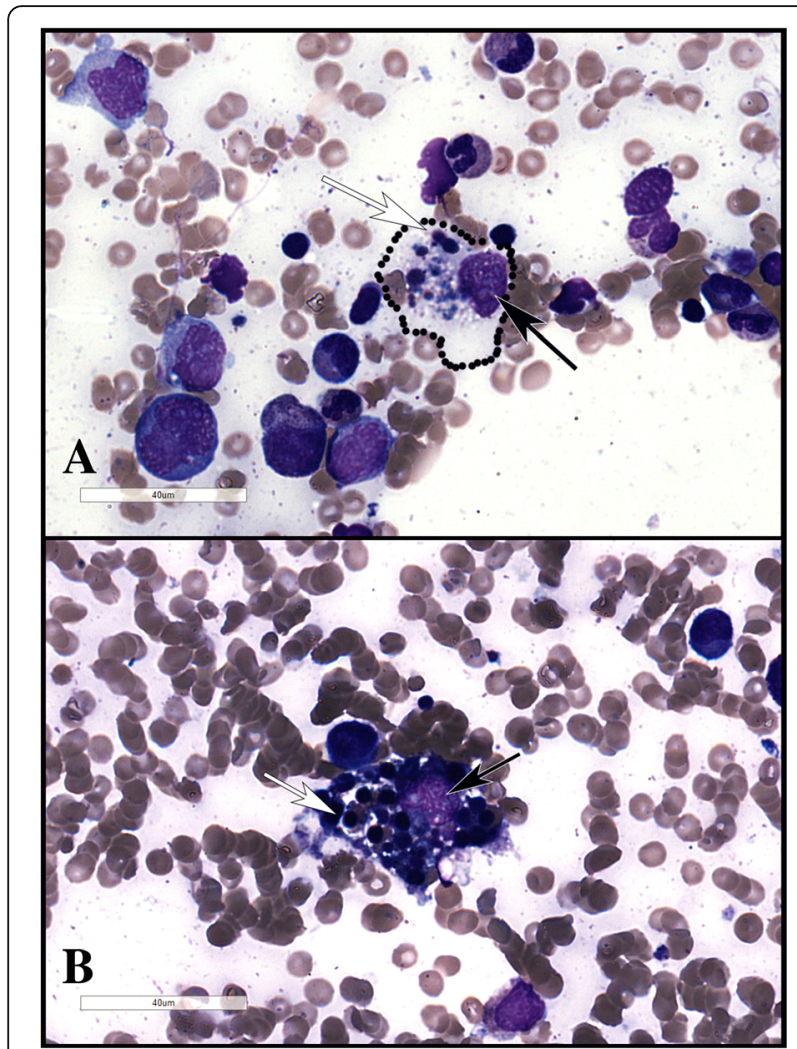

Fig. 1 A compilation of two photomicrographs from the bone marrow aspirate with a Giemsa stain. In both images $\mathbf{a}$ and $\mathbf{b}$, high-power views of hemophagocytic histiocytes are shown, with the histiocyte nucleus highlighted by the black-colored arrow and the partially-digested nuclei of phagocytosed cells highlighted by the white-colored arrow. The cytoplasmic border of the histiocyte of interest in image $A$ is highlighted by the dotted line. Giemsa staining is performed using air dried aspirate smears

A diagnosis of acute HIV infection with secondary HLH was made based on criteria from the HLH-2004 trial [1]. A secondary diagnosis of acute kidney injury secondary to rhabdomyolysis occurring in association with the acute HIV seroconversion illness was also made. The MRSA bacteremia was secondary to a subcutaneous abscess in his upper left thigh and the $S$. mitis bacteremia was thought to be secondary to the bleeding gums as a portal of entry. He was immediately started on an anti-retroviral therapy (ART) regimen consisting of lamivudine $300 \mathrm{mg}$ once daily, dolutegravir $50 \mathrm{mg}$ once daily and rilpivirine $25 \mathrm{mg}$ once daily,based on his overall findings, local resistance patterns to first generation non-nucleoside reverse transcriptase inhibitors and the desire for rapid drop in viral load given the underlying manifestations of his HIV infection.

After five weeks of ART, the plasma RNA viral load had decreased to less than 100 copies/mL and his CD4+ count had increased to $0.275 \times 10^{9} / \mathrm{L}$. His platelets, CK, ferritin and creatinine normalized. He responded well to

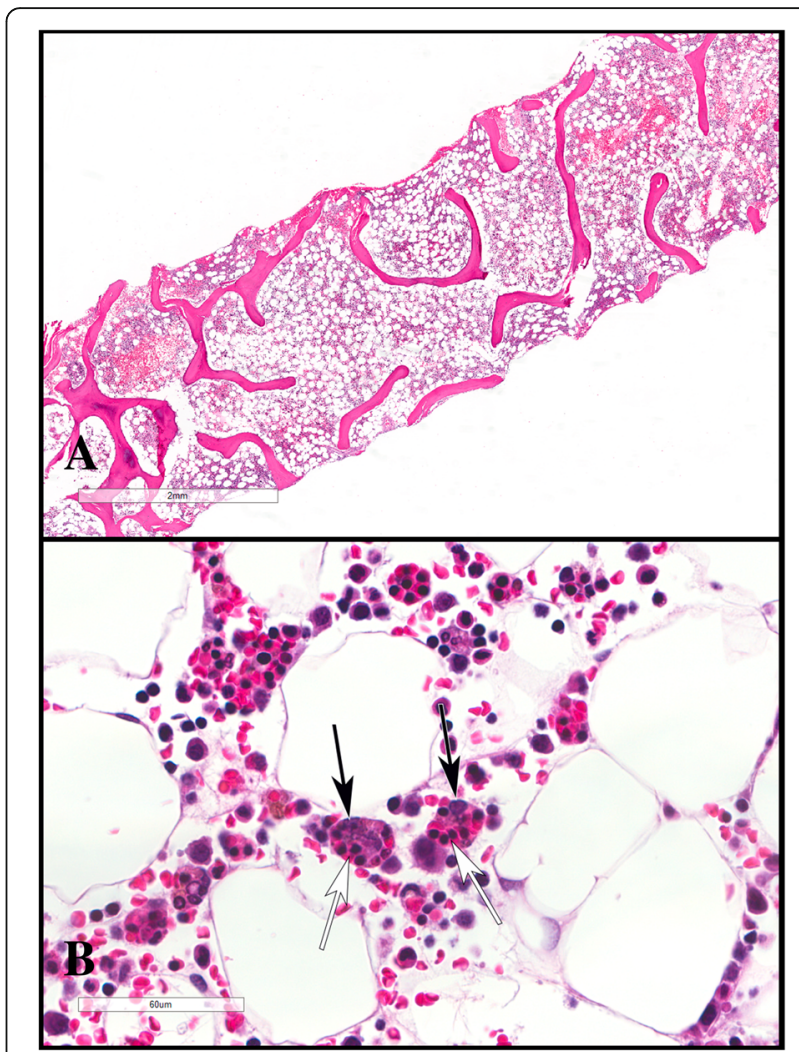

Fig. 2 A compilation of two photomicrographs from the bone marrow biopsy with a Hematoxylin/Eosin (H\&E) stain. In image a, a low-power image, the hypocellularity of the marrow (considering the patient's young age) is highlighted. In image b, a high-power image, several hemophagocytic histiocytes can be seen. Both have a saccular appearance (their nuclei are highlighted by the black-colored arrow), dilated by phagocytosed marrow elements (whose partially-digested nuclei are highlighted with the white-colored arrow). H\&E biopsy stains are prepared on formalin-fixed paraffin embedded bone marrow biopsy materials that are briefly decalcified in formic acid

two weeks of intravenous vancomycin and remained adherent to ART. The risk factor for HIV infection remains unclear. By three months follow up, he had developed a full band profile of antibodies to HIV on Western blotting, the viral load was undetectable and all other results had normalized.

\section{Discussion}

Acute HIV infection may be asymptomatic in about half of patients [13]. Symptomatic acute HIV infection presents with nonspecific features such as fever, pharyngitis, lymphadenopathy, a diffuse maculopapular rash, myalgia and malaise although other atypical presentations have been described in the literature [14].

The diagnosis of HLH can be made based on criteria from the HLH-2004 trial but is difficult to diagnose clinically with a broad differential diagnosis including infections, 
neoplasms, inflammatory disorders and immunodeficiencies (Table 1) [1].

HLH is a rare presentation of an acute HIV infection; based on a literature search of articles in English, we were able to find 10 documented cases of adults who presented with HLH secondary to an acute HIV infection [5-12]. Due to its rarity, diagnosis is often difficult, delaying treatment. In this case, a markedly elevated ferritin increased suspicion for HLH which, along with the thrombocytopenia, prompted a bone marrow biopsy. As part of the work up for an underlying cause of HLH, a rapid HIV assay was ordered which was negative. All HIV antibody tests are known to miss the "window period" of acute HIV infection between infection and antibody production [15]. As such, fourth generation antigen/antibody assays along with plasma viral load must be used for diagnosis as per Centers for Disease Control and Prevention guidelines [16].

In cases of secondary HLH, no immunomodulators are used but rather treatment of the primary condition is given to control the acute inflammatory cascade that results in HLH. We used no immunomodulatory therapy and chose, in the absence of resistance testing, an empiric regimen to suppress viremia rapidly in an effort to reduce the active HLH related co-morbidities.

This case report suggests that acute HIV infection needs to be considered when the cause of HLH is not apparent. While rapid HIV antibody testing is fast and easily accessible, its limitations in diagnosis of early HIV need to be acknowledged as it cannot be used to exclude acute infection prior to the antibody response. The value of solid testing algorithms and use of fourth generation antigenantibody assays with molecular testing for a definitive diagnosis are affirmed by this case. With HLH, consideration of all its etiologies with appropriate diagnostic testing is required. While the differential for secondary HLH is broad, consideration of the clinical context can help dictate what kind of testing needs to be done.

\section{Conclusion}

$\mathrm{HLH}$ as a presentation of acute HIV infection is rare and potentially life threatening. HLH is a complex multisystem disease and requires the involvement of different disciplines including experts in the fields of infectious diseases, hematology, immunology and pathology for diagnosis and management. Following any diagnosis of $\mathrm{HLH}$, rapid identification and treatment of the underlying condition is critical. Our case suggests that a negative rapid HIV antibody test can be misleading in the context of early HIV infection and the additional use of fourth generation antigen/antibody test or plasma RNA viral load may be required within the right clinical context for diagnosis.

\section{Abbreviations}

ART: Antiretroviral therapy; CK: Creatine kinase; HIV: Human

immunodeficiency virus; HLH: Hemophagocytic lymphohistiocytosis

\author{
Acknowledgements \\ The authors would like to thank Dr. Kevin Fonseca, ProvLab Alberta, Alberta \\ Health Services and at the University of Calgary for his guidance and \\ interpretation of the virology data.
}

Funding

This case report was not funded.

Availability of data and materials

Not applicable.

\section{Authors' contributions}

FM did the literature search and wrote up the first draft of the case report. EW assisted in the decision making for the management of the case and was involved in providing guidance and editing of the manuscript. EM was responsible for the hematopathology assessment and interpretation and providing guidance and editing of the manuscript. JG and JC were senior authors and were involved in the decision making for the management of the case, interpreting the results of the laboratory testing, editing and providing their expertise. All authors approved of the final edited manuscript.

Ethics approval and consent to participate

Not applicable.

\section{Consent for publication}

Consent has been obtained from the patient for the publishing of this case report and any accompanying data. Additionally, consent has been obtained for the publishing of images from his bone marrow biopsy. This consent has been explicitly documented in the patient's clinical chart.

\section{Competing interests}

The authors declare that they have no competing interests.

\section{Publisher's Note}

Springer Nature remains neutral with regard to jurisdictional claims in published maps and institutional affiliations.

\section{Author details}

${ }^{1}$ University of Calgary and Alberta Health Services, 1403-29th Street NW, Calgary, AB T2N 2T9, Canada. ${ }^{2}$ Foothills Medical Centre, Alberta Health Services-Calgary and Area, Room AGW5, Foothills Medical Centre, 1403-29th Street NW, Calgary, AB T2N 2T9, Canada.

Received: 23 March 2017 Accepted: 12 September 2017 Published online: 20 September 2017

References

1. Henter Jl, Horne A, Arico M, et al. HLH-2004: diagnostic and therapeutic guidelines for hemophagocytic lymphohistiocytosis. Pediatr Blood Cancer. 2007:48:124-31.

2. Colomba C, Di Carlo P, Scarlata F, laria C, Barberi G, Famà F, Cama V, Cascio A. Visceral leishmaniasis, hypertriglyceridemia and secondary hemophagocytic lymphohistiocytosis. Infection. 2016;44(3):391-2.

3. Cascio A, Pernice LM, Barberi G, Delfino D, Biondo C, Beninati C, Mancuso G, Rodriguez-Morales AJ, laria C. Secondary hemophagocytic lymphohistiocytosis in zoonoses. A systematic review. Eur Rev Med Pharmacol Sci. 2012;16(10):1324-37.

4. Doyle T, Bhagani S, Cwynarski K. Haemophagocytic syndrome and HIV. Curr Opin Infect Dis. 2009;22(1):1-6.

5. Pellegrin JL, Merlio JP, Lacoste D, et al. Syndrome of macrophagic activation with hemophagocytosis in human immunodeficiency virus infection. Rev Med Interne. 1992;13:438-40.

6. Pontes J, Mateo O, Gaspar G, et al. Hemophagocytosis syndrome associated with acute HIV infection. Enferm Infecc Microbiol Clin. 1995;13:441-2.

7. Martinez-Escribano JA, Pedro F, Sabater V, et al. Acute exanthem and pancreatic panniculitis in a patient with primary HIV infection and haemophagocytic syndrome. Br J Dermatol. 1996;134:804-7. 
8. Chen TL, Wong WW, Chiou TJ. Hemophagocytic syndrome: an unusual manifestation of acute human immunodeficiency virus infection. Int J Hematol. 2003;78:450-2.

9. Park KH, Yu HS, Jung SI, Shin DH, Shin JH. Acute human immunodeficiency virus syndrome presenting with hemophagocytic lymphohistiocytosis. Yonsei Med J. 2008;49(2):325-8.

10. Sun HY, Chen MY, Fang CT, Hsieh SM, Hung CC, Chang SC. Hemophagocytic lymphohistiocytosis: an unusual initial presentation of acute HIV infection. J Acquir Immune Defic Syndr. 2004;37(4):1539-40.

11. Concetta C, Roberta P, Giuliana B, Antonio C, Vito G, Silvia C, Orlando A. Hemophagocytic syndrome in a patient with acute human immunodeficiency virus infection. Clin Infect Dis. 2004;38(12):1792-3.

12. Adachi E, Koibuchi T, Imai K, Kikuchi T, Shimizu S, Koga M, Nakamura H, Iwamoto A, Fujii T. Hemophagocytic syndrome in an acute human immunodeficiency virus infection. Intern Med. 2013:52(5):629-32.

13. Cohen MS, Gay CL, Busch MP, Hecht FM. The detection of acute HIV infection. J Infect Dis. 2010;202(Supplement 2):S270-7.

14. Sterling TR, Chaisson RE. General clinical manifestations of human immunodeficiency virus infection (Including acute retroviral syndrome and oral, cutaneous, renal, ocular, metabolic, and cardiac diseases). In: Mandell, Douglas, and Bennett's principles and practice of infectious diseases. Elsevier Inc. 2014;1:1541.e1-1557.e5.

15. Peters PJ, Westheimer E, Cohen $\mathrm{S}$, et al. Screening yield of HIV antigen/ antibody combination and pooled HIV RNA testing for acute HIV infection in a high-prevalence population. JAMA. 2016;315(7):682-90.

16. Centers for Disease Control and Prevention and Association of Public Health Laboratories. Laboratory testing for the diagnosis of HIV infection: updated recommendations. 2014. http://stacks.cdc.gov/view/cdc/23447. Accessed 23 Nov 2016.

\section{Submit your next manuscript to BioMed Central and we will help you at every step:}

- We accept pre-submission inquiries

- Our selector tool helps you to find the most relevant journal

- We provide round the clock customer support

- Convenient online submission

- Thorough peer review

- Inclusion in PubMed and all major indexing services

- Maximum visibility for your research

Submit your manuscript at www.biomedcentral.com/submit 